Nd:YAG laser treatment for hair-dye-induced Riehl's melanosis. J Cosmet Laser Ther 2015;17:135-138.

3. Wang L, Xu AE. Four views of Riehl's melanosis: clinical appearance, dermoscopy, confocal microscopy and histopathology. J Eur Acad Dermatol Venereol 2014;28:11991206.

4. Park JY, Kim YC, Lee ES, Park KC, Kang HY. Acquired bilateral melanosis of the neck in perimenopausal women. Br J Dermatol 2012;166:662-665.

5. Braun RP, Rabinovitz HS, Oliviero M, Kopf AW, Saurat JH. Dermoscopy of pigmented skin lesions. J Am Acad Der- matol 2005;52:109-121.

6. Choi YH, Kim D, Hwang E, Kim BJ. Skin texture aging trend analysis using dermoscopy images. Skin Res Technol 2014; 20:486-497.

7. Kim E, Cho G, Won NG, Cho J. Age-related changes in skin bio-mechanical properties: the neck skin compared with the cheek and forearm skin in Korean females. Skin Res Technol 2013;19:236-241.

8. Lallas A, Apalla Z, Lefaki I, Sotiriou E, Lazaridou E, loannides $D$, et al. Dermoscopy of discoid lupus erythematosus. $\mathrm{Br} J$ Dermatol 2013;168:284-288.

\title{
Therapeutic Effect of 308-nm Excimer Laser on Alopecia Areata in an Animal Model
}

\author{
Jong Hyuk Moon, Chan Yl Bang, Min Ji Kang, Seung Dohn Yeom, Hee Seong Yoon, Hyo Jin Kim, \\ Ji Won Byun, Jeonghyun Shin, Gwang Seong Choi
}

Department of Dermatology, Inha University Hospital, Inha University School of Medicine, Incheon, Korea

\section{Dear Editor:}

Alopecia areata (AA) is an autoimmune disease characterized by round patches of alopecia with distinct margins ${ }^{1}$. Genetic, autoimmune, and epigenetic factors are known to contribute to the development of $A A^{1}$. Among these factors, a follicle-specific T-cell-mediated autoimmune reaction is considered most important ${ }^{1}$. Specifically, CD4 + and CD8 + T-lymphocytes are involved in the primary pathogenesis of $A^{1,2}$. Natural killer group 2D positive $(\mathrm{NKG} 2 \mathrm{D}+)$ cells such as NK, NKT, and CD8 $+\mathrm{T}$ cells and NKG2D activating ligands from the MHC I-related chain A family also have a key role in pathogenesis ${ }^{2}$. CD4 + / CD25 + T-cells are also involved ${ }^{3,4}$. Most therapies of AA target the autoimmune reaction, but a new therapy modality is being needed because of limitations and complications of previous therapies ${ }^{5}$. There are many reports on use of 308-nm excimer laser therapy for $\mathrm{AA}^{6-10}$, but the exact mechanism of effect is unknown. Thus, we performed histopathologic evaluation after 308-nm excimer laser therapy in an animal AA model to investigate therapeutic mechanism of excimer laser therapy on AA. This study was conducted using $\mathrm{C} 3 \mathrm{H} / \mathrm{HeJ}$ mice with $\mathrm{AA}$ patches. AA patches of $\mathrm{C} 3 \mathrm{H} / \mathrm{HeJ}$ mice were grafted via full-thickness skin graft (FTSG) from 46-week-old C3H/HeJ mice that naturally developed AA patches as aging process. After 50 days from the date of FTSG, all of five mice had AA patches on the back. AA patches induced on the back skin of five $\mathrm{C} 3 \mathrm{H} / \mathrm{HeJ}$ mice were treated with 308-nm

\footnotetext{
Received December 19, 2017, Revised July 19, 2018, Accepted for publication August 13, 2018
}

Corresponding author: Gwang Seong Choi, Department of Dermatology, Inha University Hospital, Inha University School of Medicine, 27 Inhang-ro, Jung-gu, Incheon 22332, Korea. Tel: 82-32-890-2238, Fax: 82-32-890-2236, E-mail: garden@inha.ac.kr ORCID: https://orcid.org/0000-0002-5766-0179

This is an Open Access article distributed under the terms of the Creative Commons Attribution Non-Commercial License (http://creativecommons.org/ licenses/by-nc/4.0) which permits unrestricted non-commercial use, distribution, and reproduction in any medium, provided the original work is properly cited.

Copyright (C) The Korean Dermatological Association and The Korean Society for Investigative Dermatology 
excimer laser (XTRAC ${ }^{\circledR}$ Ultra; Photomedex, Montgomeryville, PA, USA). To determine the minimal erythema dose (MED), the laser is examined in 10 sites starting with 100 $\mathrm{mJ}$ and increasing by $30 \mathrm{~mJ}$ to $370 \mathrm{~mJ}$ and MED is determined by the dose at which erythema occurs after 24 hours. AA patches were divided into control (left side) and treated areas (right side), based on a cephalocaudal axis. The laser was used on a patch of alopecia on the right back twice a week for 12 weeks, at the same MED.

We performed skin biopsies before and after laser therapy on both sides of AA patches in 4 mice. Each biopsy specimen was fixed in 10\% buffered formalin and embedded in paraffin, then stained with hematoxylin and eosin (H\&E). Immunohistochemical studies were conducted for CD4 and CD8 receptors (Thermo Fisher Scientific, Fremont, CA, USA). Positive CD4 and CD8 staining for perifollicular cells was divided into four grades: 0 , none; 1 , mild;
2, moderate; 3, severe. Two dermatologists and one pathologist reviewed the histopathology.

Perifollicular CD4 + and CD8 + T-lymphocytes infiltration were evaluated before and after 12 weeks of laser therapy using the Wilcoxon rank-sum test. Data were analyzed with IBM SPSS Statistics ver. 19.0 (IBM Corp., Armonk, NY, USA). Statistical significance was set at $p<0.05$. This study was approved by the Institutional Animal Care and Use Committees of Inha University (INHA120516-143).

As a result, hair regrowth was grossly observed on the area treated with the excimer laser. Because one mouse died at 6 weeks, 4 mice were used to evaluate gross hair regrowth (Fig. 1). In 3 of the 4 mice, gross hair regrowth was observed on treated areas, but not on untreated areas (Fig. $1 \mathrm{~L} \sim \mathrm{N}$ ). One mouse showed similar hair regrowth on both sides (Fig. 1O).

After 12 weeks of therapy, the number of hair follicles in-

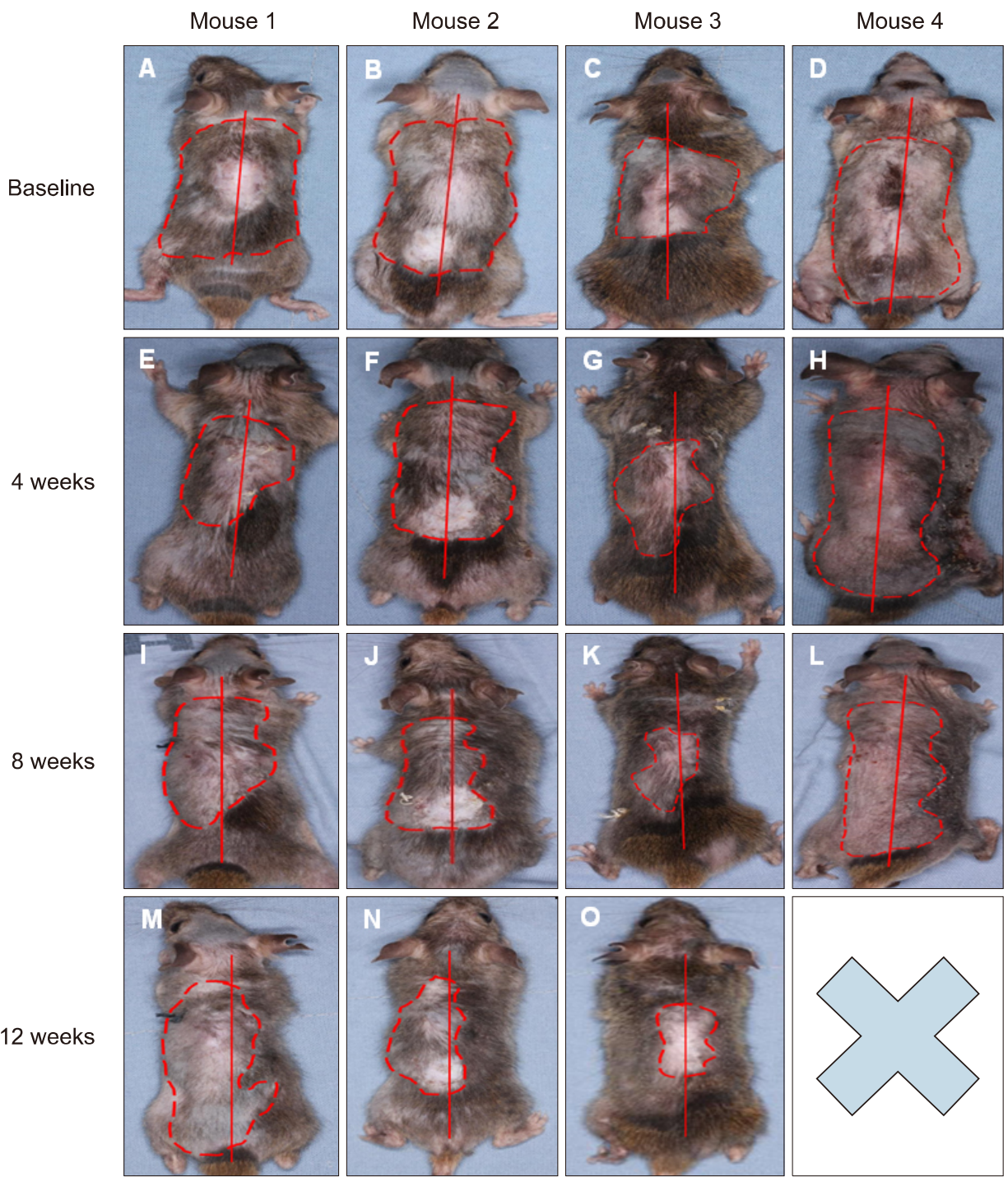

Fig. 1. Gross hair regrowth on the control and treated side. Comparison of the baseline $(A \sim D)$ and the 12 weeks $(\mathrm{L} \sim \mathrm{O})$ shows gross hair regrowth only on the treated side in 3 mice $(\mathrm{L} \sim \mathrm{N})$, but both sides showed similar gross hair regrowth in mouse $3(\mathrm{O})$. Red line: cephalocaudal axis, red dotted line: area of alopecia areata. 


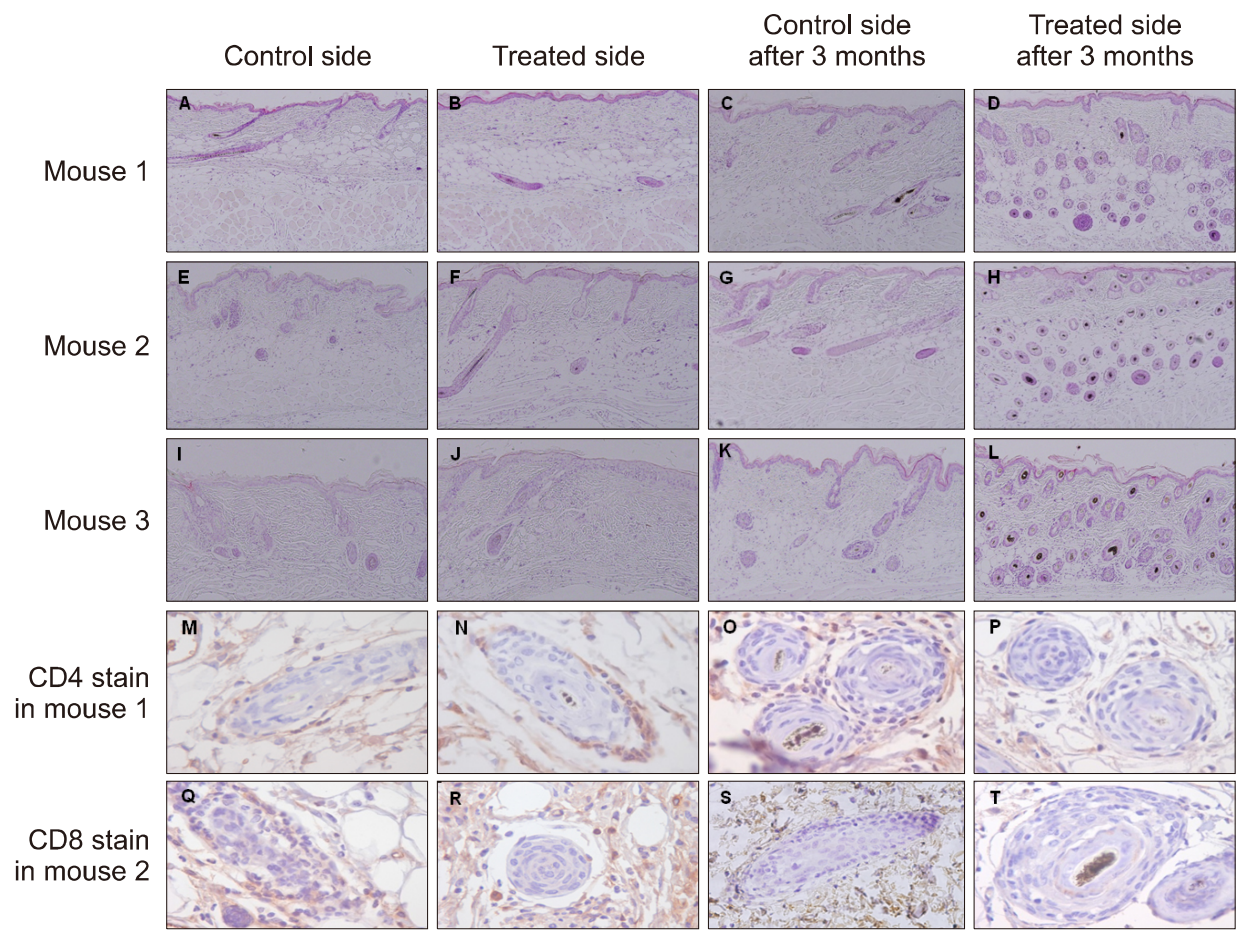

Fig. 2. Histologic appearance in control and treated area through excimer laser therapy. After 3 months of laser therapy, an increase of hair follicle number $(\mathrm{A} \sim \mathrm{L}$ : $\mathrm{H} \& \mathrm{E}, \times 100)$ and a decrease of CD4+/CD8+ T-cell infiltration ( $\mathrm{M} \sim \mathrm{T}$ : $\mathrm{CD} 4$ stain, CD8 stain, $\times 400$ ) were detected on the treated side. creased and perifollicular lymphocytic infiltration decreased in treated areas in 3 mice on H\&E stain. Only 1 mouse showed an increase in the number of hair follicles in the control area (Fig. 2A $\sim \mathrm{L}$ ).

Perifollicular CD4 + and CD8 + T-cell infiltration decreased after excimer laser therapy (Fig. 2M T). The degree of CD4 + perifollicular T cells decreased significantly on the right side of AA patches compared to the left side after laser therapy (mean scores before treatment [left/right]: mouse $1 ; 2.33 / 3$, mouse $2 ; 3 / 3$, mouse $3 ; 2 / 2.33$, Mean scores after treatment [left/right]: mouse $1 ; 2 / 1.33$, mouse $2 ; 2.66 / 2$, mouse $3 ; 2.33 / 1.66)(p=0.0495)$. The number of CD8 + perifollicular T cells also decreased significantly on the right side of AA patches compared to the left side after laser therapy (mean scores before treatment [left/ right]: mouse $1 ; 2.33 / 2.33$, mouse $2 ; 2.33 / 2.66$, mouse 3 ; $1.66 / 1.66$, mean scores after treatment [left/right]: mouse $1 ; 2 / 1.33$, mouse $2 ; 2 / 1.66$, mouse $3 ; 1.33 / 0.66) \quad(p=$ $0.025)$.

The mechanism of hair regrowth induced by the excimer laser is not yet known, but it was suggested that the laser induced apoptosis of T-cells and/or exerted immunomodulatory activity through water-soluble mediators ${ }^{7}$. The 308-nm wavelength is too short to penetrate human hair follicles affected by inflammatory cells; however, soluble mediators could be involved in inhibition of $\mathrm{T}$ cell-mediated autoimmune reactions ${ }^{8}$. Topical application of the immunosuppressive agent FK506 to $\mathrm{C} 3 \mathrm{H} / \mathrm{HeJ}$ mouse skin induced a decrease in perifollicular and/or intrafollicular
$\mathrm{CD} 4+$ and $\mathrm{CD} 8+\mathrm{T}_{\text {-cell infiltration }}{ }^{10}$. These results suggest that cytotoxic T-lymphocytes played the important role in development of $\mathrm{AA}$.

There are some limitations to this study. First, this study includes the small sample size of mice. Second, it is known that 308-nm excimer laser has no effectiveness on alopecia totalis and alopecia universalis and in this regard, our study showed that the clinical effect of excimer laser in AA animal model was limited because of the diffuse alopecic patch. Third, treatment and non-treatment area is too close that non-treatment areas can also have therapeutic effects. In addition, future studies are needed to define which mechanism is involved in a decrease of CD4 + and CD8 + T-cell infiltration after the 308-nm excimer laser therapy and to investigate changes in NK cells. In conclusion, we investigated the therapeutic effects of the 308-nm excimer laser in AA. These data demonstrate that the 308-nm excimer laser reduces perifollicular CD4 + and CD8 + T-cell infiltration and it could be considered as an alternative therapy option for AA.

\section{ACKNOWLEDGMENT}

This work was supported by the Inha University Research Grant.

\section{CONFLICTS OF INTEREST}

The authors have nothing to disclose. 


\section{ORCID}

Jong Hyuk Moon, https://orcid.org/0000-0002-1070-4963

Chan YI Bang, https://orcid.org/0000-0002-0776-0163

Min Ji Kang, https://orcid.org/0000-0003-2844-7341

Seung Dohn Yeom, https://orcid.org/0000-0001-6171-2843

Hee Seong Yoon, https://orcid.org/0000-0001-8997-9697

Hyo Jin Kim, https://orcid.org/0000-0002-0186-0593

Ji Won Byun, https://orcid.org/0000-0003-0317-6725

Jeonghyun Shin, https://orcid.org/0000-0002-4995-9533

Gwang Seong Choi, https://orcid.org/0000-0002-5766-0179

\section{REFERENCES}

1. Alkhalifah A, Alsantali A, Wang E, McElwee KJ, Shapiro J. Alopecia areata update: part I. Clinical picture, histopathology, and pathogenesis. J Am Acad Dermatol 2010;62: 177-188.

2. Pratt $\mathrm{CH}$, King LE Jr, Messenger AG, Christiano AM, Sundberg JP. Alopecia areata. Nat Rev Dis Primers 2017;3:17011.

3. Zöller M, McElwee KJ, Engel P, Hoffmann R. Transient CD44 variant isoform expression and reduction in $\mathrm{CD} 4(+) / \mathrm{CD} 25(+)$ regulatory $\mathrm{T}$ cells in $\mathrm{C} 3 \mathrm{H} / \mathrm{HeJ}$ mice with alopecia areata. J Invest Dermatol 2002;118:983-992.

4. Kaufman G, d'Ovidio R, Kaldawy A, Assy B, Ullmann Y,
Etzioni A, et al. An unexpected twist in alopecia areata pathogenesis: are NK cells protective and CD49b+ T cells pathogenic? Exp Dermatol 2010;19:e347-e349.

5. Novák Z, Bónis B, Baltás E, Ocsovszki I, Ignácz F, Dobozy $A$, et al. Xenon chloride ultraviolet $B$ laser is more effective in treating psoriasis and in inducing $T$ cell apoptosis than narrow-band ultraviolet B. J Photochem Photobiol B 2002; 67:32-38.

6. Al-Mutairi N. 308-nm excimer laser for the treatment of alopecia areata. Dermatol Surg 2007;33:1483-1487.

7. Byun JW, Moon JH, Bang CY, Shin J, Choi GS. Effectiveness of 308-nm excimer laser therapy in treating alopecia areata, determined by examining the treated sides of selected alopecic patches. Dermatology 2015;231:70-76.

8. Cetin ED, Savk E, Uslu M, Eskin M, Karul A. Investigation of the inflammatory mechanisms in alopecia areata. Am J Dermatopathol 2009;31:53-60.

9. McElwee KJ, Rushton DH, Trachy R, Oliver RF. Topical FK506: a potent immunotherapy for alopecia areata? Studies using the Dundee experimental bald rat model. $\mathrm{Br}$ J Dermatol 1997;137:491-497.

10. McElwee KJ, Boggess D, King LE Jr, Sundberg JP. Experimental induction of alopecia areata-like hair loss in $\mathrm{C} 3 \mathrm{H} / \mathrm{HeJ}$ mice using full-thickness skin grafts. J Invest Dermatol 1998;111:797-803. 